\title{
The R-spondin/Lgr5/Rnf43 module: regulator of Wnt signal strength
}

\author{
Wim de Lau, ${ }^{1}$ Weng Chuan Peng, ${ }^{2}$ Piet Gros, ${ }^{2}$ and Hans Clevers ${ }^{1,3}$ \\ ${ }^{1}$ Hubrecht Institute, Royal Netherlands Academy of Arts and Sciences (KNAW), University Medical Centre Utrecht, \\ 3584 CT Utrecht, The Netherlands; ${ }^{2}$ Crystal and Structural Chemistry, Bijvoet Center for Biomolecular Research, \\ Department of Chemistry, Faculty of Science, Utrecht University, $3584 \mathrm{CH}$ Utrecht, The Netherlands
}

Lgr5 was originally discovered as a common Wnt target gene in adult intestinal crypts and colon cancer. It was subsequently identified as an exquisite marker of multiple Wnt-driven adult stem cell types. Lgr5 and its homologs, Lgr4 and Lgr6, constitute the receptors for R-spondins, potent Wnt signal enhancers and stem cell growth factors. The Lgr5/R-spondin complex acts by neutralizing Rnf43 and Znrf3, two transmembrane E3 ligases that remove Wnt receptors from the stem cell surface. Rnf43/Znrf3 are themselves encoded by Wnt target genes and constitute a negative Wnt feedback loop. Thus, adult stem cells are controlled by an intricate interplay of potent Wnt agonists, antagonists, and anti-antagonists.

After mouse Wntl and its fly homolog, wingless, were discovered as oncogene and morphogen, respectively, studies on Wnt signaling focused primarily on animal development. Indeed, Wnts were found as ubiquitous instructive signals during development, directing cell fate and patterning in all animals (Clevers and Nusse 2012). Two simultaneous observations shifted attention to the adult organism: (1) The colorectal tumor suppressor gene APC was discovered as a negative regulator of the Wnt pathway, and (2) genetic ablation of Wnt signaling resulted in a failure to build intestinal crypt stem cell compartments. Similar findings were subsequently reported in several additional tissues. This review focuses on the complex physical and functional interactions of three recently discovered protein families that control stem cell activity by regulating surface expression of Wnt receptors: the seven-transmembrane (7TM) receptor Lgr5 and its homologs, the single-pass transmembrane E3 ligases Rnf43 and Znrf3, and the secreted R-spondin ligands.

\section{Intestinal crypt homeostasis}

The epithelium of the intestine forms a single-cell-layered barrier between the hazardous chemical and biological contents of the gut lumen and our bodies. Likely because

[Keywords: Lgr5; Rnf43/Znrf3; Rspondin; Wnt signal regulation] ${ }^{3}$ Corresponding author

E-mail h.clevers@hubrecht.eu

Article is online at http://www.genesdev.org/cgi/doi/10.1101/gad.235473.113. of this, it undergoes intense self-renewal. With its renewal cycle of 4-5 d, it is the fastest proliferating tissue in adult animals (Leblond and Stevens 1948; Clevers 2013). The epithelium of the small intestine (Fig. 1) is organized into repetitive units, consisting of villi that protrude into the lumen and are surrounded at their base by the crypts of Lieberkühn, invaginations into the underlying connective tissue. Villi serve to maximize the surface epithelium for uptake of nutrients (Fig. 1). New epithelial cells are constantly born in the crypts (Fig. 1). Stem cells reside at crypt bottoms, while transit-amplifying (TA) cells make up the remainder of the crypts. TA cells rapidly divide four to five times prior to their differentiation upon crossing the crypt villus junction (Marshman et al. 2002). This organization results in a continuous migration of cells along the crypt-villus axis in a conveyor belt-like fashion. Cells ultimately reach the tip of the villus and are shed into the lumen. The proliferative activity and the acquisition of particular cell fates are coordinated by a small number of conserved signaling pathways, most notably the Wnt/ $\beta$-catenin and the Notch signaling pathways.

Wnt signals drive self-renewal of the healthy intestinal epithelium

The first genetic mouse experiment implying Wnt signaling in adult stem cell biology (Fig. 1) involved the deletion of the Tcf4/Tcf712 gene (Korinek et al. 1998). Tcf4 constitutes the nuclear effector of Wnt signaling that, when bound by the key regulated protein $\beta$-catenin, will activate Wnt target gene expression (Fig. 2). Absence of this transcription factor completely blocks development of the intestinal crypts. The same phenotype was reported for transgenic mice in which Wnt signaling was inhibited using Dickkopf-1 (Dkk1) (see Fig. 2; Pinto et al. 2003; Kuhnert et al. 2004), Dkk1 being a secreted Wnt antagonist (Glinka et al. 1998). Along these lines, the induced deletion in adult mice of the $\beta$-catenin gene (Ireland et al.

(C) 2014 de Lau et al. This article is distributed exclusively by Cold Spring Harbor Laboratory Press for the first six months after the full-issue publication date (see http://genesdev.cshlp.org/site/misc/terms.xhtml). After six months, it is available under a Creative Commons License (Attribution-NonCommercial 3.0 Unported), as described at http:// creativecommons.org/licenses/by-nc/3.0/. 

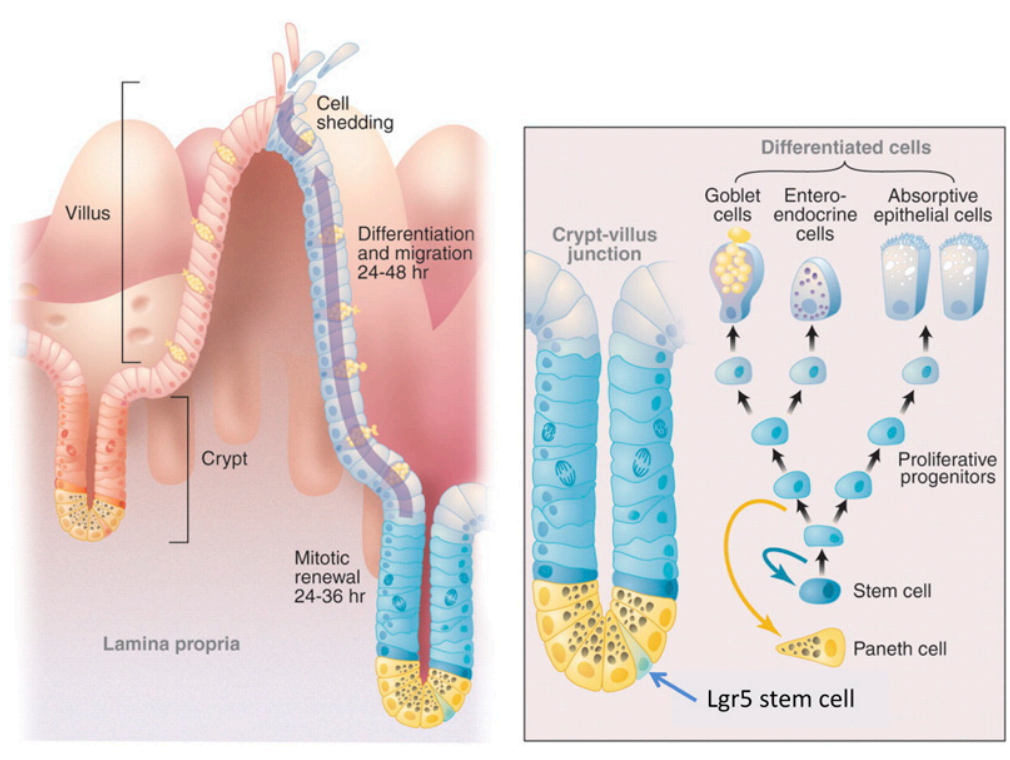

Figure 1. Architecture of the intestinal epithelium. The small intestinal lumen is lined with a specialized simple epithelium consisting of crypts and villi. Four types of differentiated epithelial cells cover these villi: the absorptive enterocytes, mucous-secreting goblet cells, hormone-secreting enteroendocrine cells, and tuft cells. The crypts of Lieberkühn, epithelial invasions into the underlying connective tissue, harbor Lgr5 stem cells and their progeny, the TA cells. Cycling Lgr5 stem cells are interspersed with terminally differentiated Paneth cells at crypt bottoms. Small numbers of noncycling secretory progenitors located near the crypt bottom have recently been demonstrated to represent a noncycling "reserve" stem cell population (Buczacki et al 2013).

2004; Fevr et al. 2007) or Tcf4 (Fig. 2; van Es et al. 2012) blocks all crypt stem cell activity.

As the mirror image of this phenomenon, it was found that the colon cancer tumor suppressor adenomatous polyposis coli (APC) serves as a negative regulator of $\beta$-catenin stability. Levels of free cytoplasmic $\beta$-catenin are normally exceedingly low but rapidly increase upon Wnt signaling, after which $\beta$-catenin can engage and activate Tcf4. APC was observed to bind $\beta$-catenin (Rubinfeld et al. 1993; Su et al. 1993). In Apc mutant colon cancer cells, $\beta$-catenin levels are aberrantly increased (Munemitsu et al. 1995), leading to the inappropriate activation of Tcf4 target genes (Korinek et al. 1997). The same effect occurs when the $\beta$-catenin gene sustains activating point mutations (Morin et al. 1997; Rubinfeld et al. 1997). The Wnt/Tcf4-driven genetic program in colon cancer was first determined by microarraying in 2002 (van de Wetering et al. 2002). Upon further refinement, this program was found to consist of a core of $\sim 80 \mathrm{Tcf} 4$ target genes. Most of these are expressed by proliferative TA crypt cells. A limited number is detected specifically in post-mitotic Paneth cells that reside at crypt bottoms (Van der Flier et al. 2007).
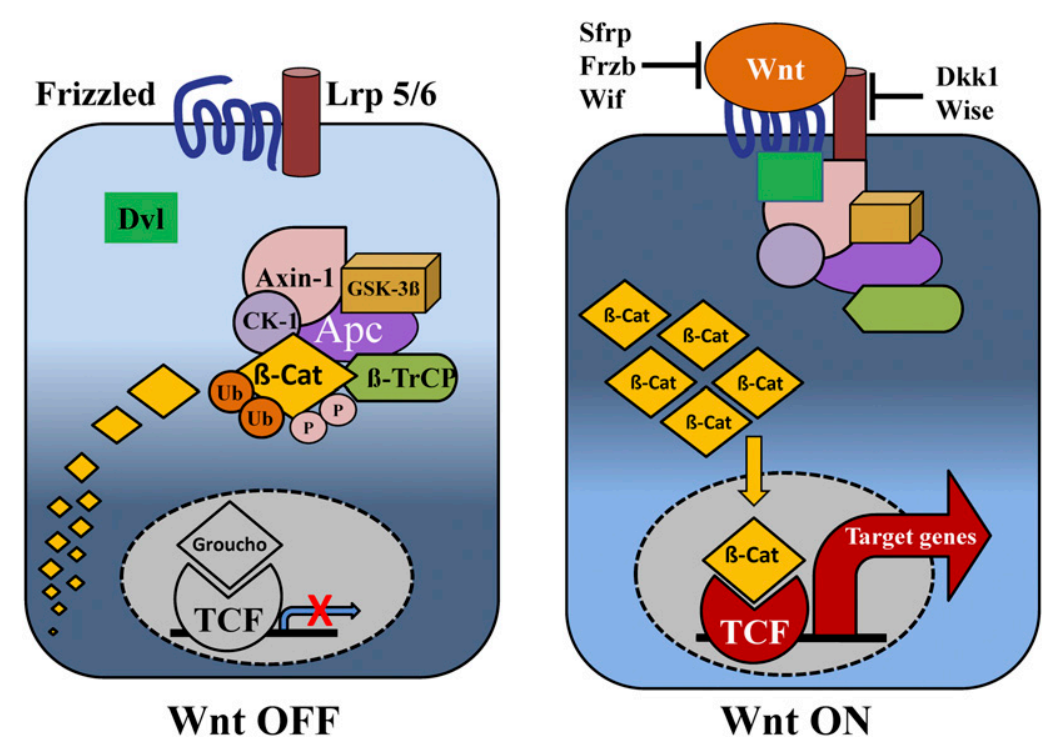

Figure 2. Canonical Wnt signaling (Nusse 2012). In cells devoid of a Wnt signal, free cytoplasmic $\beta$-catenin is actively targeted for degradation. This is accomplished by two scaffolding proteins (Apc and Axin) that bind $\beta$-catenin. They reside in the so-called destruction complex. Two kinases (CkI and Gsk3 $\beta$ ) present in the same destruction complex sequentially phosphorylate a set of highly conserved Ser and Thr residues of $\beta$-catenin. Phospho-modified $\beta$-catenin becomes a substrate of the ubiquitin E3 ligase $\beta$-Trcp and is subsequently degraded in proteasomes. In the absence of Wnt signaling, Groucho proteins determine the nuclear DNA-binding proteins of the Tcf/Lef family to act as transcriptional repressors of Wnt target genes. Secreted Wnt proteins (19 family members) can induce signaling by interacting with Wnt receptor complexes consisting of a member of the Frizzled family (10 members) and the low-density lipid receptor family members Lrp5 or Lrp6. Wnt binding inactivates the destruction complex. As a direct consequence, $\beta$-catenin accumulates in the cytoplasm and nucleus and binds to members of the Tcf/Lef family, converting these into transcriptional activators. The Wnt signaling pathway is regulated extensively at the receptor-ligand level (Cruciat and Niehrs 2013). Secreted Frizzled-related proteins (Sfrp and Frzb) and Wnt inhibitory factor (WIF) can bind Wnt directly to prevent activation of receptors. Other Wnt antagonists, DKK1 and Wise, inhibit by binding to the LRP coreceptor. Recently discovered additional stem cell-specific regulators of canonical Wnt signaling (including Lgr4-6; the R-spondins; Rnf43; and its paralog, Znrf3) are the subject of this review. 


\section{Lgr5 marks intestinal stem cells}

One of the Tcf4 target genes, Lgr5/Gpr49, was expressed in a unique fashion; i.e., in small, cycling cells at the bottom of the crypts. These so-called "crypt base columnar" (CBC) cells were identified originally by Paneth in 1887 (Paneth 1887), were described in detail by Cheng and Leblond (1974) through electron microscopy, and were postulated to represent the intestinal stem cells. LacZ and GFP knock-in mouse models confirmed the CBC-specific expression of Lgr5. An Lgr5 locus-specific CreERT2 mouse was then crossed with the Rosa26-LacZ Cre reporter mouse. This Lgr5-based lineage tracing experiment provided definitive evidence for stemness of the CBC cell. Within $5 \mathrm{~d}$, blue "ribbons" spanning the entire crypt-villus axis were formed, which persisted throughout life (Barker et al. 2007). Included in these ribbons were all known types of differentiated cells. Collectively, the experiments demonstrated that the cycling Lgr $5^{+}$stem cells are long-lived and multipotent. Small numbers of noncycling secretory progenitors located near the crypt bottom have recently been demonstrated to represent a noncycling "reserve" stem cell population (Buczacki et al. 2013).

Using the same lineage tracing strategy, Lgr5 was subsequently found to mark stem cells in many other organs and tissues, including the stomach (Barker et al. 2010), pancreas (Huch et al. 2013a), liver (Huch et al. 2013b), kidney (Barker et al. 2012), and mammary gland (de Visser et al. 2012; Plaks et al. 2013). Lgr4, a close homolog of Lgr5, is coexpressed with Lgr5 in CBC cells but is expressed by all other crypt cells (de Lau et al. 2011). This pattern-Lgr5 marks active stem cells, while Lgr4 marks the entire compartment-appears to be a recurrent phenomenon in adult Wnt-driven stem cell compartments.

\section{Lgr4, Lgr5, and Lgr6 are members of the Rhodopsin family of GPCRs}

This triad of stem/progenitor cell-expressed receptors belongs to a subgroup of eight LGRs within the superfamily of Rhodopsin GPCRs (Fig. 3). The LGR family is defined by a large extracellular domain (ECD) composed of a string of leucine-rich repeat (LRR) units. This LRR region is flanked by $\mathrm{N}$-terminal and $\mathrm{C}$-terminal cap modules. The eight LGRs can be further subdivided into class A, B, and C receptors (Van Loy et al. 2008; Van Hiel et al. 2012). A-type receptors contain seven to nine LRRs and a long Hinge region connecting the LRR region with the 7TM domain. They include Lgr1, the follicle-stimulating hormone receptor (FSHR); Lgr2, the luteinizing hormone receptor (LHR); and Lgr3, the thyroid-stimulating hormone receptor (TSHR) (Fig. 3). Type C receptors Lgr7 and Lgr8 resemble type A receptors but have a shorter Hinge region and are characterized by the presence of a LDLa motif (Fig. 3). They bind the insulin-like relaxins, peptide hormones that act as essential factors regulating pregnancy and parturition. Ligand binding by type $\mathrm{A}$ and type $\mathrm{C}$ results in conformational changes in the Rhodopsin-like transmembrane region with subse-

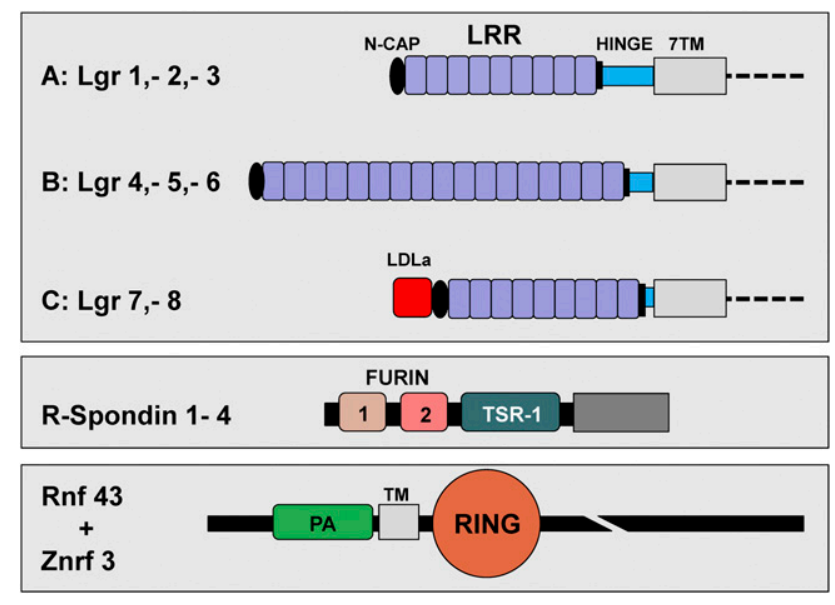

Figure 3. Schematic representation of the domain composition of Lgr1-8, R-spondin1-4, and Rnf43/Znrf3. The eight members of the Lgr family of GPCRs are characterized by the presence of a large ECD composed of LRRs. This domain is flanked by $\mathrm{N}$ terminal and $\mathrm{C}$-terminal caps and a C-terminal Hinge region connecting the LRR domain with the 7TM. They can be further subdivided into classes A, B, and C. The class A receptor family comprises Lgr1, Lgr2, and Lgr3, which are receptors for the glycoprotein hormones follicle-stimulating hormone, luteinizing hormone, and thyroid-stimulating hormone, respectively. Individual human A-type receptors contain nine LRRs and a relatively long Hinge domain. The class B receptor family consists of Lgr4, Lgr5, and Lgr6. The ECD consists of 17 LRRs, and their Hinge domain is of intermediate length. Lgr7 and Lgr8 constitute the class C receptor family. Both bind insulin-like peptide hormones. They exhibit a very short Hinge domain. They are distinguished by the presence of an LDLa N-terminal domain that is essential for signaling. R-spondin proteins harbor two Furin repeats, both required for Wnt signal enhancement. The Furin-1 domain interacts with RNF43/ZNRF3, while the Furin-2 domain binds Lgr4-6. The TSR-1 domain binds Syndecan-type cell surface receptors. RNF43 and ZNRF3 are homologous RING-type E3 ligases and are structurally related to Grail. Typically, these single-pass transmembrane proteins have an extracellular PA domain and a cytoplasmic RING domain. The E3 ubiquitin ligase activity exerted by the RING domains of Rnf43 and Znrf3 targets lysine residues in the 7TM loops of Frizzled receptors. Substrate recognition may be dependent on an interaction of their associated PA domain with the Frizzled-LRP5/6 Wnt receptor complex.

quent G-protein-driven elevation of intracellular cAMP (Hsu et al. 2005; Park et al. 2005). In every phylum containing type A or type C Lgrs, except Cnidaria, sequences related to their putative ligands are found. This suggests the existence of coevolution of respective receptor/ligand pairs. For type B Lgrs, this situation may be less obvious. The bestcharacterized nonmammalian B-type receptor is Drosophila Lgr2. Its ligand, Bursicon, a glycoprotein-like heterodimeric cysteine knot protein, is involved in tanning, cuticle hardening, and wing expansion at an adult stage (Luo et al. 2005). This hormone is well conserved in insects, mollusks, and echinoderms but not in the more primitive chordates.

In the absence of a known ligand, the functions of Lgr4/5/6 were first explored by reverse genetics. For mouse Lgr4, a broad expression pattern was noted, with particularly 
strong activity in the cartilage, heart, hair follicles, kidneys, reproductive tracts, and nervous system cells (Van Schoore et al. 2005). In addition, antibody staining on human tissues detected pancreatic islets (Yi et al. 2013). Lgr4 targeted mice showed severe intrauterine growth retardation. Most animals that survived until birth died in the first days after (Mazerbourg et al. 2004; Kato et al. 2006). Neonatal null mice displayed a variety of abnormalities: male infertility (Mazerbourg et al. 2004; Hoshii et al. 2007; Li et al. 2010; Mohri et al. 2010; Qian et al. 2013), impaired prostate development (Luo et al. 2013), defective uterine development (Sone et al. 2013), delayed development of mammary ducts (Oyama et al. 2011; Wang et al. 2013c), severe abnormalities in the anterior segment of the eye (Song et al. 2008; Weng et al. 2008), abnormal erythropoiesis (Song et al. 2008), defective osteoblast differentiation (Luo et al. 2009), renal defects (Kato et al. 2006; Mohri et al. 2011), defective development of the gall bladder (Yamashita et al. 2009), eye-open phenotype (Kato et al. 2007; Jin et al. 2008), and abnormalities in hair follicle development (Mohri et al. 2008). In addition, ablation of Lgr4 in mice appears to promote the white-to-brown fat switch, leading to energy expenditure (Wang et al. 2013b). Hypomorphic Lgr4 mice, expressing $10 \%$ of normal Lgr4 mRNA, showed embryonic/perinatal lethality and male infertility and displayed morphologic abnormalities similar to Lgr4-null mice (Hoshii et al. 2007; Yamashita et al. 2009). Interestingly, a nonsense C376T mutation seen in the Icelandic population is associated with several human diseases, resembling the murine phenotypes (Styrkarsdottir et al. 2013)

The expression of Lgr5 occurs in stem cells at sites of active proliferation and is the direct consequence of active Wnt signaling. Not unexpectedly, Lgr5 expression occurs also in colon cancer (van de Wetering et al. 2002; McClanahan et al. 2006). Likely as a result of Wnt pathway mutations, Lgr5 is also strongly expressed in cancers of the ovary, liver, and lung (Yamamoto et al. 2003; McClanahan et al. 2006; Zucman-Rossi et al. 2007; Tanese et al. 2008). Homozygous disruption of Lgr5 results in neonatal lethality due to ankyloglossia, a fusion of the tongue to the floor of the oral cavity (Morita et al. 2004). The origin of this abnormality corresponds with the expression of Lgr5 in the epithelium of the tongue and in the mandible of developing embryos. Conditional deletion of Lgr5 in the intestines of adult mice revealed no overt phenotype, while deletion of Lgr4 reduced the proliferation of CBC cells in intestinal crypts (de Lau et al. 2011). The combined removal of Lgr4 and Lgr5 aggravated this phenotype, abolishing the crypt stem cell compartment. Microarraying indicated that removal of Lgr4 and Lgr5 specifically affected expression of the Wnt-driven crypt program, implying a functional connection between the two Lgrs and the Wnt pathway. Finally, homozygous mutant Lgr6 mice displayed no apparent phenotype (Snippert et al. 2010).

\section{R-spondins, vertebrate-specific Wnt-agonists}

The four secreted R-spondin proteins are unique agonists of Wnt-initiated signaling (Fig. 3). The first experimental evidence revealing this role for R-spondins came from an expression screen in early frog embryos (Kazanskaya et al. 2004). Depletion of R-spondin 2 in single blastomeres at the eight-cell stage in early frog embryos or depletion at the gastrula stage resulted in a failure to transcriptionally activate the myoD and myf5 genes, leading to impaired muscle development. Manipulation of basal Wnt activity at this developmental stage in chicks and mammals phenocopied these effects (Cossu and Borello 1999; Borycki and Emerson 2000). Wnt reporter assays in HEK293T cells confirmed the suggested functional link between canonical Wnt/ $\beta$-catenin signaling and R-spondin activity (Kazanskaya et al. 2004). R-spondins were found to act immediately upstream of Wnt proteins. Accordingly, R-spondin-driven Wnt activation was sensitive to the presence of the extracellular Wnt receptor inhibitor Dkk1 (Fig. 2). In a subsequent study, transgenic mice were generated in which circulating lymphocytes constitutively secrete R-spondin-1. These mice displayed a colossal expansion of their intestinal crypts. The same study confirmed that R-spondin-1 enhances Wnt signal strength, as measured by $\beta$-catenin stabilization and phosphorylation of the Wnt/Frizzled coreceptor Lrp6 (Kim et al. 2005). Of interest, gene fusions that affect R-spondin-2 and R-spondin-3 and lead to higher expression levels of functional R-spondin have been reported in a subset of human colon cancers (Seshagiri et al. 2012).

$\mathrm{R}$-spondin-1 is an essential component of a threedimensional (3D) culture system that allows long-term growth of intestinal epithelial organoids from $\mathrm{Lgr}^{+} \mathrm{CBC}$ cells (Sato et al. 2009). In this culture system, isolated single stem cells are suspended in Matrigel, a 3D lamininand collagen-rich matrix that mimics the basal lamina. A cocktail of R-spondin, EGF, and Noggin provides the essential stem cell maintenance signals. R-spondin was chosen for its Wnt signal-enhancing activity, while its mechanism of action was then still unknown. The resulting organoids ("mini-guts") recapitulate essentially all aspects of the self-renewing crypt-villus epithelium and can be expanded for years in culture while remaining genetically and phenotypically stable (Sato and Clevers 2013). Similar protocols have been developed for Lgr5 stem cells from the liver (Huch et al. 2013b), stomach (Barker et al. 2010), and pancreas (Huch et al. 2013a).

The R-spondins are members of a much larger family of proteins characterized by the presence of thrombospondin repeats (TSRs) (Fig. 3). R-spondins uniquely combine the TSR with two N-terminal Furin repeats (de Lau et al. 2012). The prefix $\mathrm{R}$ in the R-spondin members refers to the observed expression of murine R-spondin 1 in the embryonic (R)oof plate neural epithelial tissue (Kamata et al. 2004). The two Furin-like cysteine-rich repeats near the $\mathrm{N}$ terminus of the mature protein represent the "business end" of the mature protein, as the presence of both repeats in R-spondin is necessary and sufficient to exert the Wnt-enhancing activity (Kazanskaya et al. 2004). The TSR-1 domain in R-spondin may serve for glycosaminoglycan/proteoglycan binding, as seen for other proteins. A recent, corresponding finding is the identification of the transmembrane proteoglycan syndecan- 4 
as the receptor for R-spondin-3 (Ohkawara et al. 2011). Rspondin homologs, defined as proteins harboring two Furin domains combined with a TSR-1 domain, are present in all vertebrates and some primitive chordates (de Lau et al. 2012). No homologs are found in invertebrate model organisms such as Drosophila and Caenorhabditis. Given this phylogenetic distribution, the first $\mathrm{R}$-spondin-like gene likely originated in the deuterostome clade. Two genome duplications generated the present-day R-spondin diversity in vertebrate species (de Lau et al. 2012).

\section{R-spondins in embryogenesis}

The unique Wnt-enhancing ability of R-spondins, combined with their dynamic expression patterns in embryonic tissues, predicts important and pleiotropic roles for R-spondins during embryogenesis (Nam et al. 2007b). A few striking examples of the decisive roles of specific $\mathrm{R}$-spondins during this stage of life are given below.

Mutations affecting the function of R-spondin-1 lead to a rare human syndrome that combines SRY-independent, $\mathrm{XX}$ male sex reversal with palmoplantar hyperkeratosis (an abnormal thickening of the palms and sole) and a predisposition to squamous cell carcinoma of the skin (Parma et al. 2006). Female sex development in the embryo is directly controlled through strong Wnt signals during differentiation of bipotential gonads. In XY individuals, the HMG-box-containing transcription factor SRY induces transcription of the HMG-box member Sox-9. This transcription factor specifically activates the program for testis development. In addition, in XX individuals, the Wnt4/ $\mathrm{R}$-spondin axis ensures female development by suppressing Sox9-driven testis development (Kashimada and Koopman 2010). The sex reversal appeared to be the consequence of a failure to mount high R-spondin-1 levels specifically during gonad differentiation of the affected XX individuals. A similar sex-reversed phenotype was observed in mice lacking R-spondin-1 or Wnt4 (Vainio et al. 1999; Tomizuka et al. 2008).

The essential role of R-spondin-2 during development was unveiled in a mouse insertion mutant, termed "footless" (Rspo2Tg/Tg), and in mice homozygous for a targeted inactivation of the R-spondin-2 gene (Nam et al. 2007a; Bell et al. 2008). Overlapping phenotypes were observed in the apical ectodermal ridge of the developing limb and in lung development. The observed lung defect results from a reduction in branching of bronchioles in the lung of $\mathrm{Rspo} 2 \mathrm{Tg} / \mathrm{Tg}$ mice. This notion was validated by in vitro R-spondin-mediated rescue of mutant lung explants. The implication of canonical Wnt signaling was further confirmed by intercrossing Rspo2 $\mathrm{Tg} / \mathrm{Tg}$ mice with Lrp6 mutant mice (Bell et al. 2008). Wnt-driven LacZ reporter mice revealed the predicted significant drop in Wnt activity at the distal tips of the branching epithelium. Reduced expression of the Wnt target gene Irx3, known to be required for branching, provided a molecular explanation for these phenotypic characteristics (van Tuyl et al. 2006). For some time now, we have known the essential role of R-spondin-1 in the develop- ment of the gonads in XX individuals. Recently, an exclusive expression of R-spondin-2 was reported in the oocytes of ovarian follicles. This oocyte-derived R-spondin appeared to direct primary follicle development to the second stage in a paracrine matter. These observations are in line with the expression of multiple Wnt ligands and cognate Frizzled receptors in the ovary (Cheng et al. 2013).

R-spondin-3 plays a dominant role during development of the placenta, which in the mouse starts at embryonic day 8.5 (E8.5) with a fusion between the chorion and allantois, two extraembryonic tissues. Subsequently, chorioallantoic branching generates a functional labyrinth, enabling exchange of gasses, nutrients, and waste products between embryonic and maternal blood vessels. An insufficient penetration of fetal blood vessels and improper alignment with maternal blood sinuses in the labyrinthine zone cause embryonic death of R-spondin-3 knockout animals at around E10. This phenotype resembles phenotypes generated by deleting either the Frizzled5 or Wnt2 gene (Monkley et al. 1996; Ishikawa et al. 2001). Finally, an R-spondin-4 gene mutation in humans results in congenital anonychia, the lack of nails on fingers and toes in otherwise healthy individuals (Blaydon et al. 2006; Khan et al. 2012).

\section{Lgr4, Lgr5, and Lgr6 are receptors for R-spondins}

Initially, candidate approaches led to claims that Fzd (Nam et al. 2006), Lrp6 (Wei et al. 2007), or the Kremen receptor (Binnerts et al. 2007) served as receptors for the R-spondins. Definitive deorphanization of the Lgrs (Fig. 3) was reported in 2012. Liu and colleagues (Carmon et al. 2011) initially tested a series of candidate ligands using classical GPCR-associated second messengers on Lgr4and Lgr5-overexpressing cell lines. In the absence of responses, they then turned to R-spondins, based on their known Wnt-agonistic role. Specific physical binding of Fc-tagged versions of R-spondins to the Lgr4- and Lgr5overexpressing cell lines and further functional and biochemical experiments revealed high-affinity interactions between Lgr4 or Lgr5 and R-spondins. In an independent approach (de Lau et al. 2011), a tagged version of R-spondin-1 was employed as a bait molecule for surface receptors on HEK293T cells. Mass spectrometry of captured proteins identified Lgr4 (de Lau et al. 2011). Indeed, gene knockdown of Lgr4 in the same cells resulted in a drop in R-spondin sensitivity. This defect could be rescued by Lgr4, Lgr5, and Lgr6 but not by other members of the Lgr subfamily. All four R-spondins were found to bind with high affinity to all three Lgrs. In intact cells, this leads to increased phosphorylation of Lrp5/6 and stabilization of $\beta$-catenin but does not involve G-protein signaling (Carmon et al. 2011; de Lau et al. 2011). A third study identified Lgr4 and Lgr5 in a genome-wide siRNA screen for R-spondin receptors and noted that $\mathrm{R}$-spondin-triggered $\beta$-catenin signaling requires Clathrin, suggesting that receptor internalization plays a mechanistic role in R-spondin signaling (Glinka et al. 2011). A fourth study confirmed Lgr4 as a cognate R-spondin receptor (Ruffner et al. 2012) 


\section{Norrin, a Wnt-agonistic alternative Lgr4 ligand}

Bursicon, the ligand of the Drosophila type B Lgr, is a glycoprotein-like heterodimeric cysteine knot protein (Luo et al. 2005). The identification of the R-spondins as ligands of the type B receptors Lgr4, Lgr5, and Lgr6 implied a change of ligand class. In addition, the failure to establish signaling through $\mathrm{G}$ proteins indicated a change in signal transduction mechanism. A recent study from Hsueh and colleagues (Deng et al. 2013) challenges this view. They propose the Wnt agonist Norrin as the ortholog of Drosophila Bursicon, based on sequence similarity and a conserved 11-cysteine structure. Accordingly, Norrin would serve as a cognate ligand for Lgr4 in addition to its widely recognized interaction with the Frizzled4 receptor (Xu et al. 2004). Norrin-liganded Lgr4 exhibited direct initiation of Wnt signaling or agonized with Wnt. Norrin did not appear to stimulate G-protein-coupled cAMP production via Lgr4, which contrasts with dLgr2/Bursicon (Luo et al. 2005).

\section{E3 ubiquitin ligases implied in Wnt-Lgr/R-spondin signaling}

The regulation of Wnt signal strength at the receptor level became even more complicated with the identification of two highly homologous Wnt target genes: Rnf43 and Znrf3. Specific Rnf43 expression was previously detected in human colon cancers (Ivanov et al. 2007). Both E3 ligases were found to be specific to Lgr5 crypt stem cells (Koo et al. 2012) and enriched in colon cancer (Hao et al. 2012). Both proteins show, in their basic structure and sequence, relatedness to Grail (Rnf128). This single-pass transmembrane E3 ligase with extracellular PA domain regulates cell surface expression of specific membrane receptors on $\mathrm{T}$ lymphocytes. Grail belongs to the Goliath family of RING domain E3 ligases. Evolutionary history as reconstructed in the Ensembl Compara database (Vilella et al. 2009) detects an ancient protein with the same domain architecture in plants, fungi, and diverse protists. Early metazoan evolution then generated two clusters. From one of these clusters, the Goliath and Godzilla families evolved. The earliest remaining representative of the second cluster is the C. elegans protein PLR-1 (Y47D3.B11). The subsequent deuterostome duplications in this cluster that generated Znrf3 and Rnf43 trace back to the base of vertebrate radiation (de Lau et al. 2012). Rnf43 and Znrf3 specifically mediate multiubiquitination of lysines in the cytoplasmic loops of the 7TM domain of Frizzleds (Hao et al. 2012; Koo et al. 2012). This results in the rapid endocytosis of Wnt receptors and their destruction in lysosomes. A similar E3 ligase-mediated mechanism to regulate the density of Frizzled receptors in the plasma membrane was very recently reported for the orthologous C. elegans PLR-1 E3 ligase (Moffat et al. 2014). The structural basis for how PLR-1, Rnf43, and Znrf3 identify Frizzleds as their specific substrates is currently not exactly known.

Rnf43 and Znrf3 specifically mediate multiubiquitination of lysines in the cytoplasmic loops of the 7TM domain of Frizzleds (Hao et al. 2012; Koo et al. 2012). This results in the rapid endocytosis of Wnt receptors and their destruction in lysosomes. The structural basis for how Rnf43 and Znrf3 identify Frizzleds as their specific substrates is currently not known.

Since Rnf43 and Znrf3 are encoded by Wnt target genes, they are presumed to function as negative feedback regulators of Wnt receptor expression. Loss of expression of these two E3 ligases is predicted to result in hyperresponsiveness to endogenous Wnt signals. Consistently, simultaneous deletion of these two Wnt modulators in the intestinal epithelium induces formation of unusual adenomas consisting entirely of Lgr5 stem cells and their niche (Koo et al. 2012). Indeed, mutations in Rnf43 are seen in some human colon cancer cell lines (Koo et al. 2012) and a variety of human tumor types affecting the bile duct (Ong et al. 2012), pancreas (Furukawa et al. 2011; Wu et al. 2011; Jiang et al. 2013), and ovary (Ryland et al. 2013; Zou et al. 2013). Of interest, the small molecule Wnt secretion inhibitor LGK974 inhibits proliferation and induces differentiation of RNF43 mutant pancreatic adenocarcinoma cell lines even when tested in xenograft models (Jiang et al. 2013).

A series of biochemical experiments indicated that the Rnf43/Znrf3-mediated membrane clearance of Wnt receptors was reversed upon addition of $\mathrm{R}$-spondin (Hao et al. 2012), implying that the R-spondin/Lgrmediated enhancement of Wnt signals involved the two E3 ligases. A weak but specific interaction of Rspondin with Znrf3 was observed. A model was then formulated in which tethering of Lgr5 and Rnf43/Znrf3 by the Furin domains of R-spondin would lead to membrane clearance of Rnf43/Znrf3. Thus, R-spondin-Lgr complexes would neutralize Rnf43/Znrf3, allowing for the persistence of surface Frizzled receptors and boosting of Wnt signal strength.

\section{The structural basis of R-spondin signaling}

A recent flurry of crystallographic studies has revealed the structure of R-spondin either alone or bound to Lgr4/5 and Rnf43/Znrf3 and provides a basis for the mechanism by which these molecules collectively control Wnt signal strength (Fig. 4A-F).

\section{R-spondin}

Signaling-competent R-spondin-1 and R-spondin-2, comprising Furin domains 1 and 2, were visualized at a resolution of $2 \AA$. Five structural studies concluded unanimously that the furin-1 and furin-2 repeats each contain three similarly constructed cysteine-knotted $\beta$ hairpins (Chen et al. 2013; Peng et al. 2013a; Wang et al. 2013a; Xu et al. 2013; Zebisch et al. 2013) with disulfide bond patterns that appear common to Furin domains seen in other proteins (Garrett et al. 1998; Ogiso et al. 2002). Overall, the two furin repeats that form a signalingcompetent fragment (Kazanskaya et al. 2004) yield an extended structure, although a flexible hinge in between furin-1 and furin-2 results in various relative domain orientations. 
A

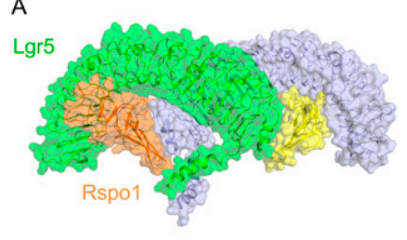

B

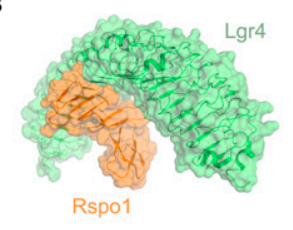

C

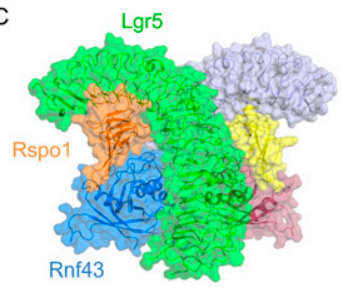

D

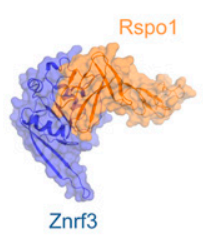

E

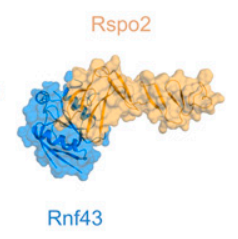

$\mathrm{F}$

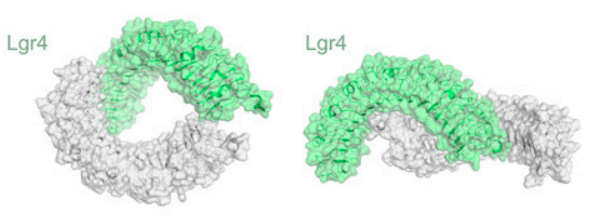

G

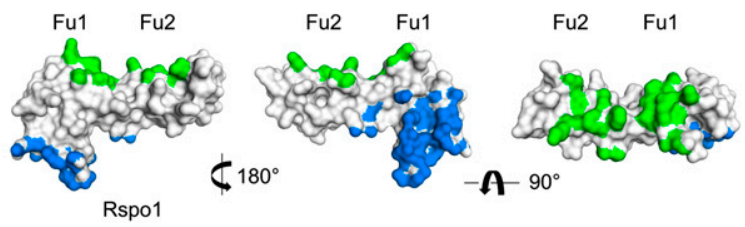

Figure 4. Crystal structures of the Lgr4/5, Rspo1/2, and Znrf3/ Rnf43 complexes. $(A-F)$ Crystal structures of various complexes in cartoon and surface representation. (A) Lgr5-Rspol (Protein Data Bank [PDB] 4BSR) (Peng et al. 2013a). (B) Lgr4-Rspo1 (PDB 4KT1) (Wang et al. 2013a). (C) Lgr5-Rspo1-Rnf43 (PDB 4KNG) (Chen et al. 2013). (D) Znrf3-Rspol (PDB 4CDK) (Peng et al. 2013b). (E) Rnf43-Rspo2 (PDB 4C9V) (Zebisch et al. 2013). (F) Lgr4 (PDB 4LI1) (Xu et al. 2013). (G) Overview of the binding interfaces of Lgr5-Rspol and Rnf43-Rspo1, based on the crystal structure of Lgr5-Rspo1-Rnf43 (PDB 4KNG) (Chen et al. 2013). Shown are the contact footprints of Lgr5 on Rspol (in green) and Rnf43 on Rspol (in blue) in orthogonal views.

\section{Lgr/R-spondin}

The large ECD of Lgr4 and Lgr5 forms an anticipated horseshoe-like structure with 17 LRRs, flanked by Lgr1type $\mathrm{N}$-terminal and C-terminal cysteine-rich caps. However, the horseshoe shape is twisted and kinked between LRR10 and LRR11. The binding position of R-spondin-1 to the concave surface of Lgr4 and Lgr5 comprises LRR domains 3-9. The first $\beta$ hairpin of the Furin-2 repeat of R-spondin-1 contains a ${ }^{106}$ FSHNF $^{110}$ loop, of which aromatic residues Phe 106 and Phe 110 form a clamp targeting Ala190 and participate in hydrophobic interaction with surrounding residues of Lgr5. Single F106E or F110E mutations in the F clamp completely abrogate receptorligand binding as well as the functional activity of R-spondin, as tested in Wnt reporter assays and small intestinal stem cell cultures (Peng et al. 2013a). Similarly, F106A and F110A mutations disrupt interaction with Lgr4 (Wang et al. 2013a; Xie et al. 2013). A second Lgr5 interaction site in R-spondin has a charged character and centers around Lys59 (Furin-1) and Arg87 (Furin-1). Mutation of these residues, although significantly reducing, did not completely abolish signaling. The R-spondin$1 /$ Lgr interface is highly conserved between all four R-spondins and Lgr4-6 in various species (Chen et al. 2013; Peng et al. 2013a; Wang et al. 2013a; Xu et al. 2013). This agrees with the previously reported promiscuity in receptor/ligand interactions.

\section{R-spondin Rnf43/Znrf3}

One group presented crystals of a trimeric complex, comprising the ECD of Rnf43 in addition to the Lgr5/ R-spondin pair (Fig. 4C; Chen et al. 2013). Lgr5 and Rnf43 receptors appear physically bridged through the furin $(1+2)$ domains of R-spondin (Fig. 4G), without a physical contact between the receptors. In addition, two studies present structural data derived from R-spondin-1/Znrf3 (Fig. 4D; Peng et al. 2013b) and R-spondin-2/Rnf43-Znrf3 (Fig. 4E; Zebisch et al. 2013). The described findings leave no doubt on the previously suggested interaction of R-spondin with RNF43 and its paralog, Znrf3. Rnf43 and Znrf3 ectodomains adopt a typical PA domain fold. Structural superposition shows high similarity with an RMSD of $0.75 \AA$. Their 3D fold compares well with that of Grail, the founder of the Goliath family, despite strong protein sequence divergence (Zebisch et al. 2013). The key elements of the electrostatic interactions in Rnf43 and Znrf3 in contact with R-spondin are Gln84, His86, Lys108, and Glu110 (positions 100, 102, 125, and 127 in human Znrf3, respectively). Conserved residues in this interface on R-spondin-1 are Ser48, Asn51, Arg66, and Gln71. A simultaneous study systematically mutating all conserved Furin repeat residues independently found that the R66A and Q71A mutations in the Furin 1 domain completely abolish R-spondin-ZNRF3 binding. All studies agree that $\mathrm{R}$-spondin-4 residues that are mutated in anonychia patients reside in the center of this interface /Chen et al. 2013; Peng et al. 2013b; Xie et al. 2013; Zebisch et al. 2013). These observations explain the inactivity of diseaserelated R-spondins in Wnt reporter assays despite intact Lgr5 binding (Peng et al. 2013a; Xie et al. 2013; Zebisch et al. 2013).

Several reports agree on a $2-5 \mathrm{nM}$ affinity interaction for the hydrophobic R-spondin/Lgr interface and a 1-10 $\mu \mathrm{M}$ affinity interaction for the mainly hydrophilic RNF43 interaction. Comparison of these affinities using bacterially produced components further confirmed these findings (Moad and Pioszak 2013). Although the Frizzled receptor clearly is a substrate for Rnf43/Znrf3-associated enzyme activity and their physical interaction was detected (Hao et al. 2012), the exact mechanism of this interaction is unknown. The weak interaction of the E3 ligases with R-spondin suggests a model for molecular competition of the PA domain with the Wnt/Lrp/Fz complex. Of note, the PA domains of PLR-1 and GRAIL are also involved in substrate recognition (Lineberry et al. 2008; Moffat et al. 2014). 
de Lau et al.

\section{Quaternary arrangements}

A puzzling aspect of the crystallographic analysis of several complexes is a variation in observed quaternary arrangements (Fig. 4). In solution, Lgr4/5 ECD-R-spondin complexes are monomeric (Peng et al. 2013a; Wang et al. 2013a), whereas Lgr4 ECD by itself has been reported to behave as a dimer (Xu et al. 2013). In multiple different crystals of Lgr5/R-spondin-1 complexes, we found dimeric, "embracing" Lgr5 ECDs (Fig. 4A; Peng et al. 2013a). Both $\mathrm{R}$-spondin molecules in the complex appeared to bind in trans to the Lgr5 C-terminal cysteine caps. This arrangement has not been observed in crystal structures reported by others. However, Xu et al. (2013) describe two head-totail Lgr4 ECDs in the asymmetric unit of their crystals (Fig. 4F, left panel). Inspection of this crystal lattice again shows a C-terminally "embraced" arrangement (Fig. 4F, right panel). Although related, this Lgr4 ECD embracement is not identical to the one seen for Lgr5/R-spondin (Fig. 4A; Peng et al. 2013a). The completely different, "back-to-back" dimer of Lgr4/R-spondin (data not shown) seen in the study of Xu et al. (2013) makes the situation even more confusing. The observed dimeric Lgr5-R-spondin arrangement (Fig. 4A) appears incompatible with Rnf43/ Znrf3 binding. The Rnf43/Znrf3 interaction site on R-spondin overlaps with the dimerization interface, including residues related to anonychia mutations. This overlap implies that dimerization would compete with Rnf43/Znrf3 binding. In addition, both Zebisch et al. (2013) and Peng et al. (2013b) observed dimers of Zrnf3rspol (data not shown) but not of Rnf43-rspol. It currently is unclear whether higher-order organization (in any form) of the receptors studied is of physiological relevance.

\section{Concluding statements}

Taken together (Fig. 5; animation at http://www.nymus3d. $\mathrm{nl} /$ video/rspondin), these observations paint a scenario in which the Lgr4, Lgr5, and Lgr6 receptors serve to efficiently recruit R-spondin ligands and bring these into position for interaction with Rnf43/Znrf3. This interaction leads to membrane clearance of the Ring finger proteins, the
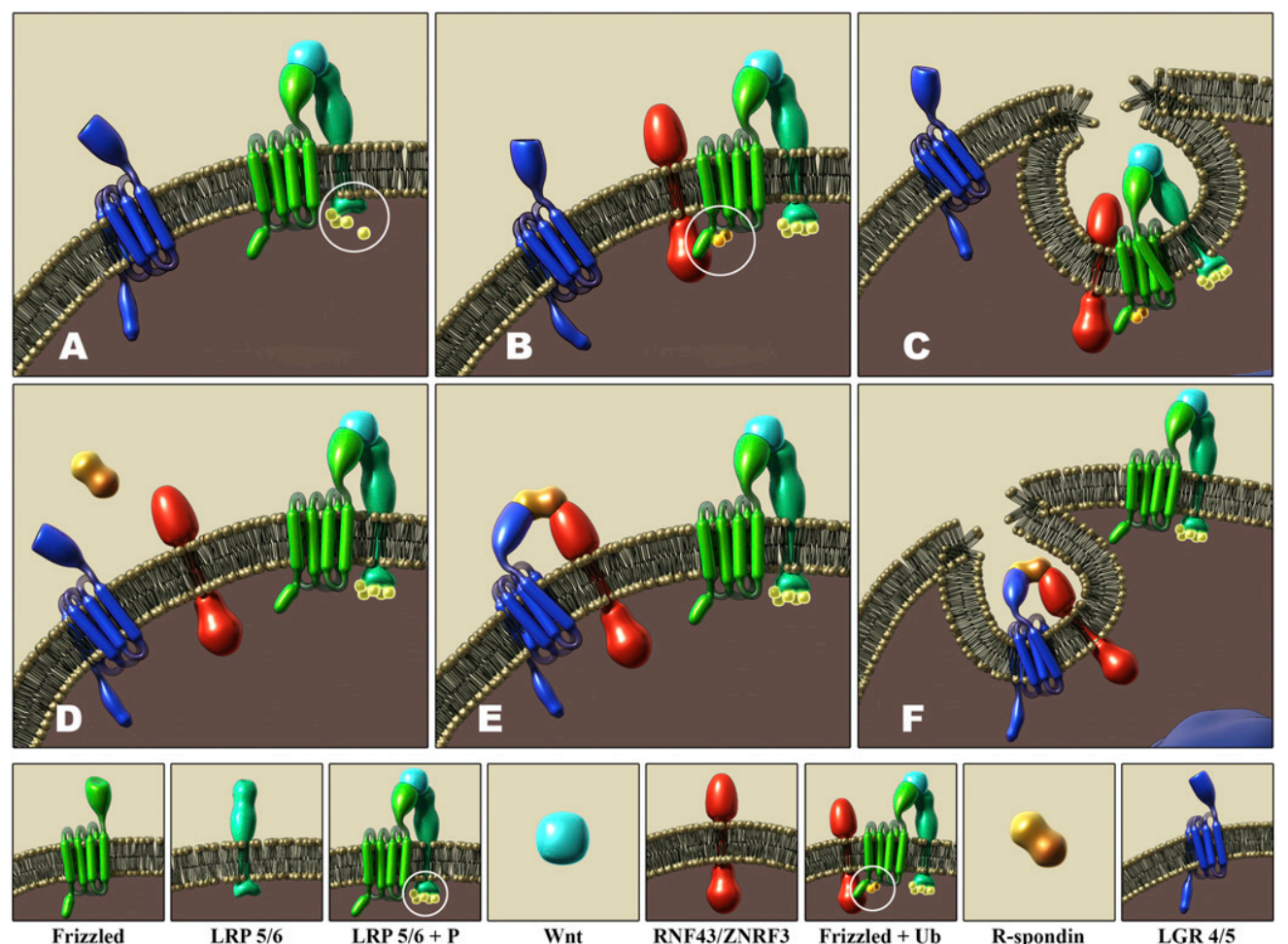

Figure 5. Regulation of Wnt receptor availability on stem cells. (Panels represent stills from animation that can be found at http:// www.nymus3d.nl/video/rspondin.) (A) Upon binding of Wnt to the Fz/LRP receptor complex, some 100 Wnt target genes are activated, including Lgr5. Two other Wnt target genes, Rnf43 and Znrf3, encode transmembrane E3 ligases containing a cytoplasmic RING domain. These serve as components of a negative feedback loop. (B) Enzymatic interaction of the Rnf43/Znrf3-associated RING domain with the Fz/LRP complex leads to polyubiquitination of the intracellular loops of the 7TM domain of Fz. $(C)$ The resulting endocytosis of $\mathrm{Fz} / \mathrm{Lrp}$ abrogates Wnt signaling. The contribution of the PA domain in the specificity of this process is unclear. Whether Rnf43/Znrf3 are endocytosed with the Wnt receptor complex or segregate after their action is also unknown. When R-spondin is present $(D)$, it is recruited to Lgr5 or its homolog, Lgr4 $(E)$. This high-affinity interaction involves the Furin-2 repeat (Fu2) of R-spondin. This then enables the Furin-1 repeat (Fu1) of R-spondin to interact with Rnf43/Znrf3 (E), resulting in the membrane clearance of the latter $(F)$. As a consequence, Wnt/Fz/Lrp receptor complexes persist on the plasma membrane, enhancing Wnt signal strength and duration. 
consequent persistence of surface Frizzled receptors, and the boosting of Wnt signal strength. The canonical Wnt signal cascade is encoded by all animal genomes, while an Rnf43/Znrf3 homolog capable of down-regulating Frizzled surface expression has been described in at least one invertebrate; i.e., PLR-1 in the roundworm C. elegans. However, the R-spondin/Lgr5/Rnf43 module appears to be a relatively recent evolutionary "add-on" seen only in vertebrates. It will be of interest to understand why this exquisite regulatory system was added to an already very complex Wnt receptor/ligand system. Answers may be found in the appearance of sophisticated stem cell/TA cell compartments in vertebrates coinciding with a general increase in body size.

\section{Acknowledgment}

We thank Johan van Es and Berend Snel for critically reading the manuscript. W.d.L. and H.C. are supported by EU FP7 grant 601876, EU ERC StemCellMark grant 232814, and CancerGenomics.nl program of the Ministerie van Onderwijs, Cultuur, en Wetenschap (OCW). W.C.P. and P.G. are supported by Nederlandse Organisatie voor Wetenschappelijk Onderzoek Spinoza grant 01.80.104.00.

\section{References}

Barker N, van Es JH, Kuipers J, Kujala P, van den Born M, Cozijnsen M, Haegebarth A, Korving J, Begthel H, Peters PJ, et al. 2007. Identification of stem cells in small intestine and colon by marker gene Lgr5. Nature 449: 1003-1007.

Barker N, Huch M, Kujala P, van de Wetering M, Snippert HJ, van Es JH, Sato T, Stange DE, Begthel $H$, van den Born $M$, et al. 2010. Lgr5(+ve) stem cells drive self-renewal in the stomach and build long-lived gastric units in vitro. Cell Stem Cell 6: 25-36.

Barker N, Rookmaaker MB, Kujala P, Ng A, Leushacke M, Snippert H, van de Wetering M, Tan S, van Es JH, Huch M et al. 2012. Lgr5(+ve) stem/progenitor cells contribute to nephron formation during kidney development. Cell Reports 2: $540-552$.

Bell SM, Schreiner CM, Wert SE, Mucenski ML, Scott WJ, Whitsett JA. 2008. R-spondin 2 is required for normal laryngeal-tracheal, lung and limb morphogenesis. Development 135: 1049-1058.

Binnerts ME, Kim KA, Bright JM, Patel SM, Tran K, Zhou M, Leung JM, Liu Y, Lomas WE 3rd, Dixon M, et al. 2007. R-Spondin 1 regulates Wnt signaling by inhibiting internalization of LRP6. Proc Natl Acad Sci 104: 14700-14705.

Blaydon DC, Ishii Y, O'Toole EA, Unsworth HC, Teh MT, Ruschendorf F, Sinclair C, Hopsu-Havu VK, Tidman N, Moss $\mathrm{C}$, et al. 2006. The gene encoding R-spondin 4 (RSPO4), a secreted protein implicated in Wnt signaling, is mutated in inherited anonychia. Nat Genet 38: 1245-1247.

Borycki AG, Emerson CP Jr. 2000. Study of skeletal myogenesis in cultures of unsegmented paraxial mesoderm. Methods Mol Biol 137: 351-357.

Buczacki SJ, Zecchini HI, Nicholson AM, Russell R, Vermeulen L, Kemp R, Winton DJ. 2013. Intestinal label-retaining cells are secretory precursors expressing Lgr5. Nature 495: 6569.

Carmon KS, Gong X, Lin Q, Thomas A, Liu Q. 2011. R-spondins function as ligands of the orphan receptors LGR4 and LGR5 to regulate Wnt/ $\beta$-catenin signaling. Proc Natl Acad Sci 108: 11452-11457.
Chen PH, Chen X, Lin Z, Fang D, He X. 2013. The structural basis of R-spondin recognition by LGR5 and RNF43. Genes Dev 27: 1345-1350.

Cheng H, Leblond CP. 1974. Origin, differentiation and renewal of the four main epithelial cell types in the mouse small intestine. V. Unitarian theory of the origin of the four epithelial cell types. Am I Anat 141: 537-561.

Cheng Y, Kawamura K, Takae S, Deguchi M, Yang Q, Kuo C, Hsueh AJ. 2013. Oocyte-derived R-spondin2 promotes ovarian follicle development. FASEB I 27: 2175-2184.

Clevers H. 2013. The intestinal crypt, a prototype stem cell compartment. Cell 154: 274-284.

Clevers H, Nusse R. 2012. Wnt/ $\beta$-catenin signaling and disease. Cell 149: 1192-1205.

Cossu G, Borello U. 1999. Wnt signaling and the activation of myogenesis in mammals. EMBO J 18: 6867-6872.

Cruciat CM, Niehrs C. 2013. Secreted and transmembrane wnt inhibitors and activators. Cold Spring Harb Perspect Biol 5: a015081.

de Lau W, Barker N, Low TY, Koo BK, Li VS, Teunissen H, Kujala P, Haegebarth A, Peters PJ, van de Wetering M, et al. 2011. Lgr5 homologues associate with Wnt receptors and mediate R-spondin signalling. Nature 476: 293-297.

de Lau WB, Snel B, Clevers HC. 2012. The R-spondin protein family. Genome Biol 13: 242.

Deng C, Reddy P, Cheng Y, Luo CW, Hsiao CL, Hsueh AJ. 2013. Multi-functional norrin is a ligand for the LGR4 receptor. J Cell Sci 126: 2060-2068.

de Visser KE, Ciampricotti M, Michalak EM, Tan DW, Speksnijder EN, Hau CS, Clevers H, Barker N, Jonkers J. 2012. Developmental stage-specific contribution of $\mathrm{LGR}^{+}$cells to basal and luminal epithelial lineages in the postnatal mammary gland. J Pathol 228: 300-309.

Fevr T, Robine S, Louvard D, Huelsken J. 2007. Wnt/ $\beta$-catenin is essential for intestinal homeostasis and maintenance of intestinal stem cells. Mol Cell Biol 27: 7551-7559.

Furukawa T, Kuboki Y, Tanji E, Yoshida S, Hatori T, Yamamoto M, Shibata N, Shimizu K, Kamatani N, Shiratori K. 2011. Whole-exome sequencing uncovers frequent GNAS mutations in intraductal papillary mucinous neoplasms of the pancreas. Scientific reports 1: 161.

Garrett TP, McKern NM, Lou M, Frenkel MJ, Bentley JD, Lovrecz GO, Elleman TC, Cosgrove LJ, Ward CW. 1998. Crystal structure of the first three domains of the type-1 insulin-like growth factor receptor. Nature 394: 395-399.

Glinka A, Wu W, Delius H, Monaghan AP, Blumenstock C, Niehrs C. 1998. Dickkopf-1 is a member of a new family of secreted proteins and functions in head induction. Nature 391: 357-362.

Glinka A, Dolde C, Kirsch N, Huang YL, Kazanskaya O, Ingelfinger D, Boutros M, Cruciat CM, Niehrs C. 2011. LGR4 and LGR5 are R-spondin receptors mediating Wnt/ $\beta$-catenin and Wnt/PCP signalling. EMBO Rep 12: 1055-1061.

Hao HX, Xie Y, Zhang Y, Charlat O, Oster E, Avello M, Lei H, Mickanin C, Liu D, Ruffner H, et al. 2012. ZNRF3 promotes Wnt receptor turnover in an $\mathrm{R}$-spondin-sensitive manner. Nature 485: 195-200.

Hoshii T, Takeo T, Nakagata N, Takeya M, Araki K, Yamamura K. 2007. LGR4 regulates the postnatal development and integrity of male reproductive tracts in mice. Biol Reprod 76: 303-313.

Hsu SY, Semyonov J, Park II, Chang CL. 2005. Evolution of the signaling system in relaxin-family peptides. Ann N Y Acad Sci 1041: 520-529.

Huch M, Bonfanti P, Boj SF, Sato T, Loomans CJ, van de Wetering M, Sojoodi M, Li VS, Schuijers J, Gracanin A, et al. 2013a. Unlimited in vitro expansion of adult bi-potent 
pancreas progenitors through the Lgr5/R-spondin axis. EMBO J 32: 2708-2721.

Huch M, Dorrell C, Boj SF, van Es JH, Li VS, van de Wetering M, Sato T, Hamer K, Sasaki N, Finegold MJ, et al. 2013b. In vitro expansion of single $\mathrm{Lgr}^{+}$liver stem cells induced by Wntdriven regeneration. Nature 494: 247-250.

Ireland H, Kemp R, Houghton C, Howard L, Clarke AR, Sansom OJ, Winton DJ. 2004. Inducible Cre-mediated control of gene expression in the murine gastrointestinal tract: Effect of loss of $\beta$-catenin. Gastroenterology 126: 1236-1246.

Ishikawa T, Tamai Y, Zorn AM, Yoshida H, Seldin MF, Nishikawa S, Taketo MM. 2001. Mouse Wnt receptor gene Fzd5 is essential for yolk sac and placental angiogenesis. Development 128: $25-33$

Ivanov I, Lo KC, Hawthorn L, Cowell JK, Ionov Y. 2007. Identifying candidate colon cancer tumor suppressor genes using inhibition of nonsense-mediated mRNA decay in colon cancer cells. Oncogene 26: 2873-2884.

Jiang X, Hao HX, Growney JD, Woolfenden S, Bottiglio C, Ng N, $\mathrm{Lu} \mathrm{B}$, Hsieh MH, Bagdasarian L, Meyer R, et al. 2013. Inactivating mutations of RNF43 confer Wnt dependency in pancreatic ductal adenocarcinoma. Proc Natl Acad Sci 110: 12649-12654.

Jin C, Yin F, Lin M, Li H, Wang Z, Weng J, Liu M, Da Dong X, Qu J, Tu L. 2008. GPR48 regulates epithelial cell proliferation and migration by activating EGFR during eyelid development. Invest Ophthalmol Vis Sci 49: 4245-4253.

Kamata $T$, Katsube K, Michikawa M, Yamada $M$, Takada S, Mizusawa H. 2004. R-spondin, a novel gene with thrombospondin type 1 domain, was expressed in the dorsal neural tube and affected in Wnts mutants. Biochim Biophys Acta 1676: $51-62$.

Kashimada K, Koopman P. 2010. Sry: The master switch in mammalian sex determination. Development 137: 39213930.

Kato S, Matsubara M, Matsuo T, Mohri Y, Kazama I, Hatano R, Umezawa A, Nishimori K. 2006. Leucine-rich repeat-containing G protein-coupled receptor-4 (LGR4, Gpr48) is essential for renal development in mice. Nephron, Exp Nephrol 104: e63-e75.

Kato S, Mohri Y, Matsuo T, Ogawa E, Umezawa A, Okuyama R, Nishimori K. 2007. Eye-open at birth phenotype with reduced keratinocyte motility in LGR4 null mice. FEBS Lett 581: 4685-4690.

Kazanskaya O, Glinka A, del Barco Barrantes I, Stannek P, Niehrs C, Wu W. 2004. R-Spondin2 is a secreted activator of $\mathrm{Wnt} / \beta$-catenin signaling and is required for Xenopus myogenesis. Dev Cell 7: 525-534.

Khan TN, Klar J, Nawaz S, Jameel M, Tariq M, Malik NA, Baig SM, Dahl N. 2012. Novel missense mutation in the RSPO4 gene in congenital hyponychia and evidence for a polymorphic initiation codon (p.M1I). BMC Med Genet 13: 120.

Kim KA, Kakitani M, Zhao J, Oshima T, Tang T, Binnerts M, Liu Y, Boyle B, Park E, Emtage P, et al. 2005. Mitogenic influence of human R-spondin1 on the intestinal epithelium. Science 309: 1256-1259.

Koo BK, Spit M, Jordens I, Low TY, Stange DE, van de Wetering M, van Es JH, Mohammed S, Heck AJ, Maurice MM, et al. 2012. Tumour suppressor RNF43 is a stem-cell E3 ligase that induces endocytosis of Wnt receptors. Nature 488: 665-669.

Korinek V, Barker N, Morin PJ, van Wichen D, de Weger R, Kinzler KW, Vogelstein B, Clevers H. 1997. Constitutive transcriptional activation by a $\beta$-catenin-Tcf complex in $\mathrm{APC}^{-/-}$colon carcinoma. Science 275: 1784-1787.

Korinek V, Barker N, Moerer P, van Donselaar E, Huls G, Peters PJ, Clevers H. 1998. Depletion of epithelial stem-cell com- partments in the small intestine of mice lacking Tcf-4. Nat Genet 19: 379-383.

Kuhnert F, Davis CR, Wang HT, Chu P, Lee M, Yuan J, Nusse R, Kuo CJ. 2004. Essential requirement for Wnt signaling in proliferation of adult small intestine and colon revealed by adenoviral expression of Dickkopf-1. Proc Natl Acad Sci 101: 266-271.

Leblond CP, Stevens CE. 1948. The constant renewal of the intestinal epithelium in the albino rat. Anat Rec 100: 357377.

Li XY, Lu Y, Sun HY, Wang JQ, Yang J, Zhang HJ, Fan NG, Xu J, Jiang JJ, Liu RY, et al. 2010. G protein-coupled receptor 48 upregulates estrogen receptor $\alpha$ expression via cAMP/PKA signaling in the male reproductive tract. Development 137: 151-157.

Lineberry N, Su L, Soares L, Fathman CG. 2008. The single subunit transmembrane E3 ligase gene related to anergy in lymphocytes (GRAIL) captures and then ubiquitinates transmembrane proteins across the cell membrane. I Biol Chem 283: 28497-28505.

Luo CW, Dewey EM, Sudo S, Ewer J, Hsu SY, Honegger HW, Hsueh AJ. 2005. Bursicon, the insect cuticle-hardening hormone, is a heterodimeric cystine knot protein that activates G protein-coupled receptor LGR2. Proc Natl Acad Sci 102: 2820-2825.

Luo J, Zhou W, Zhou X, Li D, Weng J, Yi Z, Cho SG, Li C, Yi T, $\mathrm{Wu} \mathrm{X}$, et al. 2009. Regulation of bone formation and remodeling by G-protein-coupled receptor 48. Development 136: $2747-2756$.

Luo W, Rodriguez M, Valdez JM, Zhu X, Tan K, Li D, Siwko S, Xin L, Liu M. 2013. Lgr4 is a key regulator of prostate development and prostate stem cell differentiation. Stem Cells 31: 2492-2505.

Marshman E, Booth C, Potten CS. 2002. The intestinal epithelial stem cell. BioEssays 24: 91-98.

Mazerbourg S, Bouley DM, Sudo S, Klein CA, Zhang JV, Kawamura K, Goodrich LV, Rayburn H, Tessier-Lavigne M, Hsueh AJ. 2004. Leucine-rich repeat-containing, G proteincoupled receptor 4 null mice exhibit intrauterine growth retardation associated with embryonic and perinatal lethality. Mol Endocrinol 18: 2241-2254.

McClanahan T, Koseoglu S, Smith K, Grein J, Gustafson E, Black S, Kirschmeier P, Samatar AA. 2006. Identification of overexpression of orphan G protein-coupled receptor GPR49 in human colon and ovarian primary tumors. Cancer Biol Ther 5: 419-426.

Moad HE, Pioszak AA. 2013. Reconstitution of R-spondin: LGR4:ZNRF3 adult stem cell growth factor signaling complexes with recombinant proteins produced in Escherichia coli. Biochemistry 52: 7295-7304.

Moffat LL, Robinson RE, Bakoulis A, Clark SG. 2014. The conserved transmembrane RING finger protein PLR-1 downregulates Wnt signaling by reducing Frizzled, Ror and Ryk cell-surface levels in C. elegans. Development 141: 617-628.

Mohri Y, Kato S, Umezawa A, Okuyama R, Nishimori K. 2008. Impaired hair placode formation with reduced expression of hair follicle-related genes in mice lacking Lgr4. Dev Dyn 237: 2235-2242.

Mohri Y, Umezu T, Hidema S, Tomisawa H, Akamatsu A, Kato S, Nawa A, Nishimori K. 2010. Reduced fertility with impairment of early-stage embryos observed in mice lacking Lgr4 in epithelial tissues. Fertil Steril 94: 2878-2881.

Mohri Y, Oyama K, Akamatsu A, Kato S, Nishimori K. 2011. Lgr4-deficient mice showed premature differentiation of ureteric bud with reduced expression of Wnt effector Lef1 and Gata3. Dev Dyn 240: 1626-1634. 
Monkley SJ, Delaney SJ, Pennisi DJ, Christiansen JH, Wainwright BJ. 1996. Targeted disruption of the Wnt2 gene results in placentation defects. Development 122: 3343-3353.

Morin PJ, Sparks AB, Korinek V, Barker N, Clevers H, Vogelstein B, Kinzler KW. 1997. Activation of $\beta$-catenin-Tcf signaling in colon cancer by mutations in $\beta$-catenin or APC. Science 275: $1787-1790$

Morita H, Mazerbourg S, Bouley DM, Luo CW, Kawamura K, Kuwabara Y, Baribault H, Tian H, Hsueh AJ. 2004. Neonatal lethality of LGR5 null mice is associated with ankyloglossia and gastrointestinal distension. Mol Cell Biol 24: 97369743.

Munemitsu S, Albert I, Souza B, Rubinfeld B, Polakis P. 1995. Regulation of intracellular $\beta$-catenin levels by the adenomatous polyposis coli (APC) tumor-suppressor protein. Proc Natl Acad Sci 92: 3046-3050.

Nam JS, Turcotte TJ, Smith PF, Choi S, Yoon JK. 2006. Mouse cristin/R-spondin family proteins are novel ligands for the Frizzled 8 and LRP6 receptors and activate $\beta$-catenin-dependent gene expression. J Biol Chem 281: 13247-13257.

Nam JS, Park E, Turcotte TJ, Palencia S, Zhan X, Lee J, Yun K, Funk WD, Yoon JK. 2007a. Mouse R-spondin2 is required for apical ectodermal ridge maintenance in the hindlimb. Dev Biol 311: 124-135.

Nam JS, Turcotte TJ, Yoon JK. 2007b. Dynamic expression of R-spondin family genes in mouse development. Gene Expr Patterns 7: 306-312.

Nusse R. 2012. Wnt signaling. Cold Spring Harb Perspect Biol 4:a011163.

Ogiso H, Ishitani R, Nureki O, Fukai S, Yamanaka M, Kim JH, Saito K, Sakamoto A, Inoue M, Shirouzu M, et al. 2002. Crystal structure of the complex of human epidermal growth factor and receptor extracellular domains. Cell 110: 775787.

Ohkawara B, Glinka A, Niehrs C. 2011. Rspo3 binds syndecan 4 and induces Wnt/PCP signaling via clathrin-mediated endocytosis to promote morphogenesis. Dev Cell 20: 303-314.

Ong CK, Subimerb C, Pairojkul C, Wongkham S, Cutcutache I, Yu W, McPherson JR, Allen GE, Ng CC, Wong BH, et al. 2012. Exome sequencing of liver fluke-associated cholangiocarcinoma. Nat Genet 44: 690-693.

Oyama K, Mohri Y, Sone M, Nawa A, Nishimori K. 2011. Conditional knockout of Lgr4 leads to impaired ductal elongation and branching morphogenesis in mouse mammary glands. Sex Dev 5: 205-212.

Paneth J. 1887. Ueber die secernierenden zellen des dunndarmepithels. Archiv f mikrosk Anatomie 31: 113-191.

Park JI, Semyonov J, Chang CL, Hsu SY. 2005. Conservation of the heterodimeric glycoprotein hormone subunit family proteins and the LGR signaling system from nematodes to humans. Endocrine 26: 267-276.

Parma P, Radi O, Vidal V, Chaboissier MC, Dellambra E, Valentini S, Guerra L, Schedl A, Camerino G. 2006. R-spondin1 is essential in sex determination, skin differentiation and malignancy. Nat Genet 38: 1304-1309.

Peng WC, de Lau W, Forneris F, Granneman JC, Huch M, Clevers H, Gros P. 2013a. Structure of stem cell growth factor R-spondin 1 in complex with the ectodomain of its receptor LGR5. Cell reports 3: 1885-1892.

Peng WC, de Lau W, Madoori PK, Forneris F, Granneman JC, Clevers H, Gros P. 2013b. Structures of Wnt-antagonist ZNRF3 and its complex with R-spondin 1 and implications for signaling. PLOS ONE 8: e83110.

Pinto D, Gregorieff A, Begthel H, Clevers H. 2003. Canonical Wnt signals are essential for homeostasis of the intestinal epithelium. Genes Dev 17: 1709-1713.
Plaks V, Brenot A, Lawson DA, Linnemann JR, Van Kappel EC, Wong KC, de Sauvage F, Klein OD, Werb Z. 2013. Lgr5expressing cells are sufficient and necessary for postnatal mammary gland organogenesis. Cell reports 3: 70-78.

Qian Y, Liu S, Guan Y, Pan H, Guan X, Qiu Z, Li L, Gao N, Zhao Y, Li X, et al. 2013. Lgr4-mediated Wnt/ $\beta$-catenin signaling in peritubular myoid cells is essential for spermatogenesis. Development 140: 1751-1761.

Rubinfeld B, Souza B, Albert I, Muller O, Chamberlain SH, Masiarz FR, Munemitsu S, Polakis P. 1993. Association of the APC gene product with $\beta$-catenin. Science 262: 17311734.

Rubinfeld B, Robbins P, El-Gamil M, Albert I, Porfiri E, Polakis P. 1997. Stabilization of $\beta$-catenin by genetic defects in melanoma cell lines. Science 275: 1790-1792.

Ruffner H, Sprunger J, Charlat O, Leighton-Davies J, Grosshans B, Salathe A, Zietzling S, Beck V, Therier M, Isken A, et al. 2012. R-spondin potentiates Wnt/ $\beta$-catenin signaling through orphan receptors LGR4 and LGR5. PLOS ONE 7: e40976.

Ryland GL, Hunter SM, Doyle MA, Rowley SM, Christie M, Allan PE, Bowtell DD, Gorringe KL, Campbell IG. 2013. RNF43 is a tumour suppressor gene mutated in mucinous tumours of the ovary. J Pathol 229: 469-476.

Sato T, Clevers H. 2013. Growing self-organizing mini-guts from a single intestinal stem cell: Mechanism and applications. Science 340: 1190-1194.

Sato T, Vries RG, Snippert HJ, van de Wetering M, Barker N, Stange DE, van Es JH, Abo A, Kujala P, Peters PJ, et al. 2009. Single Lgr5 stem cells build crypt-villus structures in vitro without a mesenchymal niche. Nature 459: 262-265.

Seshagiri S, Stawiski EW, Durinck S, Modrusan Z, Storm EE, Conboy CB, Chaudhuri S, Guan Y, Janakiraman V, Jaiswal BS, et al. 2012. Recurrent R-spondin fusions in colon cancer. Nature 488: 660-664.

Snippert HJ, Haegebarth A, Kasper M, Jaks V, van Es JH, Barker $\mathrm{N}$, van de Wetering $M$, van den Born $M$, Begthel $H$, Vries RG, et al. 2010. Lgr6 marks stem cells in the hair follicle that generate all cell lineages of the skin. Science 327: 13851389.

Sone M, Oyama K, Mohri Y, Hayashi R, Clevers H, Nishimori K. 2013. LGR4 expressed in uterine epithelium is necessary for uterine gland development and contributes to decidualization in mice. FASEB J 27: 4917-4928.

Song H, Luo J, Luo W, Weng J, Wang Z, Li B, Li D, Liu M. 2008. Inactivation of G-protein-coupled receptor 48 (Gpr48/Lgr4) impairs definitive erythropoiesis at midgestation through down-regulation of the ATF4 signaling pathway. J Biol Chem 283: 36687-36697.

Styrkarsdottir U, Thorleifsson G, Sulem P, Gudbjartsson DF, Sigurdsson A, Jonasdottir A, Oddsson A, Helgason A, Magnusson OT, Walters GB, et al. 2013. Nonsense mutation in the LGR4 gene is associated with several human diseases and other traits. Nature 497: 517-520.

Su LK, Johnson KA, Smith KJ, Hill DE, Vogelstein B, Kinzler KW. 1993. Association between wild type and mutant APC gene products. Cancer Res 53: 2728-2731.

Tanese K, Fukuma M, Yamada T, Mori T, Yoshikawa T, Watanabe W, Ishiko A, Amagai M, Nishikawa T, Sakamoto M. 2008. G-protein-coupled receptor GPR49 is up-regulated in basal cell carcinoma and promotes cell proliferation and tumor formation. Am J Pathol 173: 835-843.

Tomizuka K, Horikoshi K, Kitada R, Sugawara Y, Iba Y, Kojima A, Yoshitome A, Yamawaki K, Amagai M, Inoue A, et al. 2008. R-spondin 1 plays an essential role in ovarian development through positively regulating Wnt-4 signaling. Hum Mol Genet 17: 1278-1291. 
Vainio S, Heikkila M, Kispert A, Chin N, McMahon AP. 1999. Female development in mammals is regulated by Wnt-4 signalling. Nature 397: 405-409.

Van der Flier LG, Sabates-Bellver J, Oving I, Haegebarth A, De Palo $M$, Anti $M$, Van Gijn ME, Suijkerbuijk $S$, van de Wetering M, Marra G, et al. 2007. The intestinal Wnt/TCF signature. Gastroenterology 132: 628-632.

van de Wetering $M$, Sancho E, Verweij C, de Lau W, Oving I, Hurlstone A, van der Horn K, Batlle E, Coudreuse D, Haramis AP, et al. 2002. The $\beta$-catenin/TCF-4 complex imposes a crypt progenitor phenotype on colorectal cancer cells. Cell 111: 241-250.

van Es JH, Haegebarth A, Kujala P, Itzkovitz S, Koo BK, Boj SF, Korving I, van den Born M, van Oudenaarden A, Robine S, et al. 2012. A critical role for the Wnt effector Tcf4 in adult intestinal homeostatic self-renewal. Mol Cell Biol 32: 19181927.

Van Hiel MB, Vandersmissen HP, Van Loy T, Vanden Broeck J. 2012. An evolutionary comparison of leucine-rich repeat containing $G$ protein-coupled receptors reveals a novel LGR subtype. Peptides 34: 193-200.

Van Loy T, Vandersmissen HP, Van Hiel MB, Poels J, Verlinden H, Badisco L, Vassart G, Vanden Broeck J. 2008. Comparative genomics of leucine-rich repeats containing $G$ proteincoupled receptors and their ligands. Gen Comp Endocrinol 155: 14-21.

Van Schoore G, Mendive F, Pochet R, Vassart G. 2005. Expression pattern of the orphan receptor LGR4/GPR48 gene in the mouse. Histochem Cell Biol 124: 35-50.

van Tuyl M, Liu I, Groenman F, Ridsdale R, Han RN, Venkatesh V, Tibboel D, Post M. 2006. Iroquois genes influence proximo-distal morphogenesis during rat lung development. Am I Physiol Lung Cell Mol Physiol 290: L777-L789.

Vilella AJ, Severin J, Ureta-Vidal A, Heng L, Durbin R, Birney E. 2009. EnsemblCompara GeneTrees: Complete, duplicationaware phylogenetic trees in vertebrates. Genome Res 19: 327-335.

Wang D, Huang B, Zhang S, Yu X, Wu W, Wang X. 2013a. Structural basis for R-spondin recognition by LGR4/5/6 receptors. Genes Dev 27: 1339-1344.

Wang J, Liu R, Wang F, Hong J, Li X, Chen M, Ke Y, Zhang X, Ma Q, Wang R, et al. 2013b. Ablation of LGR4 promotes energy expenditure by driving white-to-brown fat switch. Nat Cell Biol 15: 1455-1463.

Wang Y, Dong J, Li D, Lai L, Siwko S, Li Y, Liu M. 2013c. Lgr4 regulates mammary gland development and stem cell activity through the pluripotency transcription factor Sox2. Stem Cells 31: 1921-1931.

Wei Q, Yokota C, Semenov MV, Doble B, Woodgett J, He X. 2007. R-spondin 1 is a high affinity ligand for LRP6 and induces LRP6 phosphorylation and $\beta$-catenin signaling. I Biol Chem 282: 15903-15911.

Weng J, Luo J, Cheng X, Jin C, Zhou X, Qu J, Tu L, Ai D, Li D, Wang J, et al. 2008. Deletion of G protein-coupled receptor 48 leads to ocular anterior segment dysgenesis (ASD) through down-regulation of Pitx2. Proc Natl Acad Sci 105: 60816086.

Wu J, Jiao Y, Dal Molin M, Maitra A, de Wilde RF, Wood LD, Eshleman JR, Goggins MG, Wolfgang CL, Canto MI, et al 2011. Whole-exome sequencing of neoplastic cysts of the pancreas reveals recurrent mutations in components of ubiquitin-dependent pathways. Proc Natl Acad Sci 108: 21188-21193.

Xie Y, Zamponi R, Charlat O, Ramones M, Swalley S, Jiang X, Rivera D, Tschantz W, Lu B, Quinn L, et al. 2013. Interaction with both ZNRF3 and LGR4 is required for the signalling activity of R-spondin. EMBO Rep 14: 1120-1126.

Xu Q, Wang Y, Dabdoub A, Smallwood PM, Williams J, Woods C, Kelley MW, Jiang L, Tasman W, Zhang K, et al. 2004. Vascular development in the retina and inner ear: Control by Norrin and Frizzled-4, a high-affinity ligand-receptor pair. Cell 116: 883-895.

Xu K, Xu Y, Rajashankar KR, Robev D, Nikolov DB. 2013. Crystal structures of Lgr4 and its complex with R-spondin1. Structure 21: 1683-1689.

Yamamoto Y, Sakamoto M, Fujii G, Tsuiji H, Kenetaka K, Asaka M, Hirohashi S. 2003. Overexpression of orphan G-proteincoupled receptor, Gpr49, in human hepatocellular carcinomas with $\beta$-catenin mutations. Hepatology 37: 528-533.

Yamashita R, Takegawa Y, Sakumoto M, Nakahara M, Kawazu H, Hoshii T, Araki K, Yokouchi Y, Yamamura K. 2009. Defective development of the gall bladder and cystic duct in Lgr4 ${ }^{-}$hypomorphic mice. Dev Dyn 238: 993-1000.

Yi J, Xiong W, Gong X, Bellister S, Ellis LM, Liu Q. 2013. Analysis of LGR4 receptor distribution in human and mouse tissues. PLOS ONE 8: e78144.

Zebisch M, Xu Y, Krastev C, Macdonald BT, Chen M, Gilbert RJ, He X, Jones EY. 2013. Structural and molecular basis of ZNRF3/RNF43 transmembrane ubiquitin ligase inhibition by the Wnt agonist R-spondin. Nat Commun 4: 2787.

Zou Y, Wang F, Liu FY, Huang MZ, Li W, Yuan XQ, Huang OP, He M. 2013. RNF43 mutations are recurrent in Chinese patients with mucinous ovarian carcinoma but absent in other subtypes of ovarian cancer. Gene 531: 112-116.

Zucman-Rossi J, Benhamouche S, Godard C, Boyault S, Grimber G, Balabaud C, Cunha AS, Bioulac-Sage P, Perret C. 2007. Differential effects of inactivated Axin1 and activated $\beta$-catenin mutations in human hepatocellular carcinomas. Oncogene 26: 774-780. 


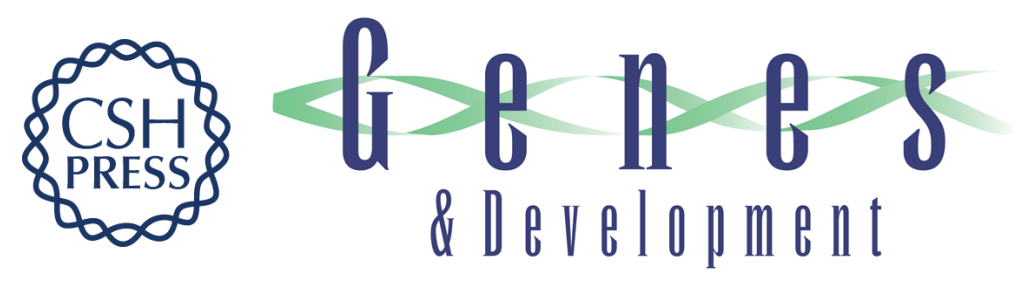

\section{The R-spondin/Lgr5/Rnf43 module: regulator of Wnt signal strength}

Wim de Lau, Weng Chuan Peng, Piet Gros, et al.

Genes Dev. 2014, 28:

Access the most recent version at doi:10.1101/gad.235473.113

References This article cites 118 articles, 43 of which can be accessed free at: http://genesdev.cshlp.org/content/28/4/305.full.html\#ref-list-1

Creative This article is distributed exclusively by Cold Spring Harbor Laboratory Press for the first Commons six months after the full-issue publication date (see License http://genesdev.cshlp.org/site/misc/terms.xhtml). After six months, it is available under a Creative Commons License (Attribution-NonCommercial 3.0 Unported), as described at http://creativecommons.org/licenses/by-nc/3.0/.

Email Alerting Receive free email alerts when new articles cite this article - sign up in the box at the top Service right corner of the article or click here.

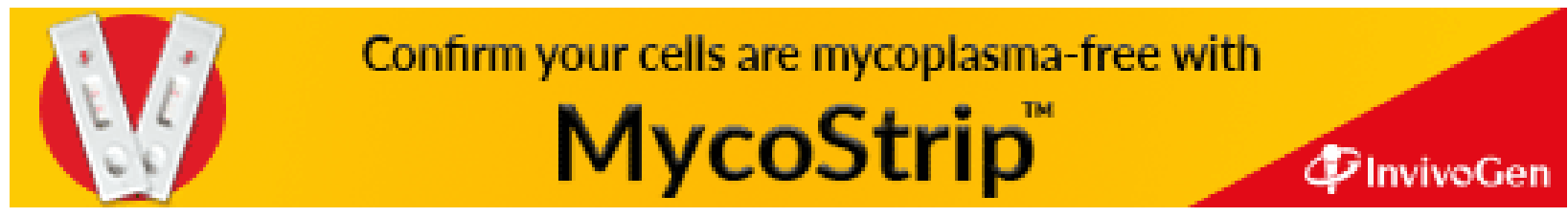

